\title{
PCR detection of Toxoplasma gondii DNA versus serological diagnosis in women suffering from repeated abortion
}

\author{
Abo EL Naga (1), AM; Shaltot (2), AA; Rizk EL- Baz(2), \\ And Eman fayad(1). \\ (1)Zoology Department, Faculty of Science at Mansoura University, Egypt. \\ (2) Genetics unit, children Hospital, Mansoura University, Egypt.
}

\begin{abstract}
Background: This study was conducted to test the utility of polymerase chain reaction (PCR) assay to detect recent infections with Toxoplasma in pregnant women. T.gondii DNA was detected by using B1 gene as a target for amplification which is highly specific for T.gondii and is well conserved among all of the tested strains.

Results: This study revealed the following findings:(1) PCR was positive in 63 subjects, including 58 high risk cases (77.3\%) and 5 of controls (12.5\%). (2) 17 high risk cases $(24.6 \%)$ had false positive IgM and 5 of controls (12.5\%) had false negative result for IgM. (3) 17 high risk cases (32.7\%) had false positive IgG and 5 of controls (12.5\%) had false negative IgG. (4) No significant association between eating raw meat or contact with cats and positive ELISA for PCR but there is highly significant association between women with contact with soil and positive PCR. (5) No significant relation between residency and either ELISA or PCR. (6) Significant negative correlation between the age of the studied women and positivity of PCR.

Conclusion: this study highlights the need for a confirmatory test to detect primary acute toxoplasmosis in pregnant women. It demonstrates the possibility of defining and selecting the high-risk cases for mother-to-child transmission of infection by combining specific serology and PCR tests to formulate a specific approach
\end{abstract}

Key words : PCR, Toxoplasma gondii and Repeated abortion.

\section{Introduction}

Primary maternal infection during pregnancy is frequently associated with transmission of T.gondii to the fetus (Wong and Remington, 1994). Transplacental transmiission of Toxoplasma from an infected, pregnant women to the unborn results in fetal damage to a degree depending on the gestational age (kopecky et al., 2001). Early - first trimester maternal infections are less likely to result in congenital infection but the sequelae are more severe (Gagne, 2001).

Transplacental passage is more common when maternal infection occurs in the latter half of pregnancy, but fetal injury is usually much less severe. It may lead to miscarriage, still birth, or congenital defects depending on the stage of gestation when the infection occurs (Dubey and Beattie, 1988). Several studies have suggested its role in the causation of abortion
(Remington et al., 1995; Sahwi et al., 1995 and Zargar et al., 1999).

Although serological testing has been one of the major diagnostic techniques for toxoplasmosis, it has many limations, for example, it may fail to detect specific antitoxoplasma immunoglobulin $\mathrm{G}$ ( $\mathrm{IgG}$ ) or IgM during the active phase of T.gondii infection, because these antibodies may not be produced until after several weeks of parasitemia. Therefore the high risk of congenital toxoplasmosis of a fetus may be undetected because the pregnant mother might test negative during the active phase of T.gondii infection. Several PCR - based techniques (Lee et al., 1999 and PujoRique et al., 1999) which have been developed for the diagnosis of Toxoplasma using various clinical specimens, including amniotic fluid (Costa et al., 1997; Hohlfeld et al., 1994), blood (Ho-yeh et al., 1992; 
Bergstrom et al., 1998 and Joss et al., 1993), cerebrospinal fluid (Roberts et al., 2001), and tissue biopsy (Johnson et al., 1993). Among these techiques, nested PCR followed by hybridization of PCR products has been the most sensitive method.

\section{Material and Methods}

This study was reviewed and approved by the Mansoura University of science, and informed consent was obtained from all the study groups.

\section{Study groups: \\ Group I: \\ Inclusion criteria:}

- Women with repeated abortion $(\geq 2$ times).

- Positive anti-Toxoplasma IgM or IgG.

- Other causes of repeated abortion were excluded.

- High risk of exposure to Toxoplasma.

This group comprised 75 cases selected randomly from patients attending Obstetric and Gynecology dapartment at Mansoura University Hospital, complaining of repeated abortions. They were collected through one year from August 2006. Age of the patients ranged from 20-30 years (mean age $25.45 \pm 2.03$ ).

\section{Group II (control group):}

This group included 40 healthy females, with normal pregnancy, matched for age, residency and socioeconomic status. Anti-Toxoplasma IgM or $\operatorname{IgG}$ was negative for all controls.

\section{Methods:}

DNA extraction

PCR amplifications:

Isolation of DNA.

DNA was isolated from blood samples using a commercial purification system (Wizard Genomic DNA Purification Kit; Promega, Madison, WI) following the manufacturer's instructions for DNA purification from blood. Final pellets were resuspended in $30 \mu \mathrm{L}$ of TE buffer $(10 \mathrm{mM}$ Tris, $1 \mathrm{mM}$ EDTA, $\mathrm{pH}$ 7.2) and stored at $20^{\circ} \mathrm{C}$ until used.

\section{Nested PCR assay}

The nested PCR was performed on all DNA samples to amplify a fragment from the B1 gene, which is present in 35 copies and is conserved in the $\boldsymbol{T}$. gondii genome, as described by (Burg et al., 1989).

\section{First cycle:}

The primers used in the first round of the PCR (inner primers) were (5'GGAACTGCATCCGTTCATGAG-3'), and (5'-TCT-TTAAAGCGTTCGTGGTC-3'), which correspond to nucleotides 694-714 and 887-868, respectively at $193 \mathrm{bp}$.

\section{Second cycle:}

The primers used in the second round (outer primers) were (5'-TGCATAG GTTGCAGTCACTG-3' and (5'-GGCGACCAATGTGC-GAATAGACC-3'), which correspond to nucleotides 757-776 and 853-831, respectively at 96bp.

Three microliters of template DNA were added to a final volume of $50 \mu \mathrm{L}$ of PCR mixture consisting of $5 \mu \mathrm{L}$ of $10 \mathrm{x}$ PCR buffer (50 mM Tris-HCl, $\mathrm{pH}$ 9.1, 3.5 $\left.\mathrm{mM} \quad \mathrm{MgCl}_{2}\right), \quad 8 \quad \mu \mathrm{L}$ of $1.25 \quad \mathrm{mM}$ deoxynucleoside triphosphates, $0.5 \mu \mathrm{L}$ of Taq DNA polymerase [5 units/ $\mu \mathrm{L}$ ], and 1.5 $\mu \mathrm{L}(20 \mathrm{pmol})$ of each of the outer primers. The amplification was performed in Hypaid thermal cycler PCR. The cycling conditions for both PCRs were $95^{\circ} \mathrm{C}$ for five minutes, followed by 30 cycles at $94^{\circ} \mathrm{C}$ for 30 seconds, $55^{\circ} \mathrm{C}$ for 90 seconds, and $72^{\circ} \mathrm{C}$ for one minute, and a final extension at $72^{\circ} \mathrm{C}$ for 10 minutes.

- Three microliters of the first-round product were used as template for the second-round PCR in a total volume of $50 \mu \mathrm{L}$ under the same conditions as in the first round, using the inner primers. DNA extracted from RH strain of $\boldsymbol{T}$. gondii from the collection of the Service de Parasitologie-Mycologie (Grenoble, France) was used as a positive control. The PCR mixture without DNA and with DNAase-free water were used as negative controls to monitor for crosscontaminations.

- One negative control and one positive control were included for every 23 samples in each PCR. The positive 
controls were loaded last to avoid contamination of the sample. To guaranty the reliability of the results and detect any possible contamination, all samples were processed in duplicate. The test result was considered positive if the amplified DNA fragment was clearly visible in both samples.

- Sample cross-contamination problems were avoided following a number of precautions including the use of aerosolguarded tips, performing DNA extraction in a laminar flow hood with subsequent irradiation by UV light and the use of three separate areas for the DNA extraction, preparation of $\mathrm{PCR}$ mixture and a separate area for PCR amplification and running gels. Five microliters of the PCR product were subjected to electrophoresis on a 1.2\% agarose gel stained with ethidium bromide (Burg $\boldsymbol{e t}$ al, 1989).

\section{Statistical analysis:}

Statistical analysis was done by computer using SPSS version 10.0. Our data was non-parametric. Comparison between various variables was done using Chi square $(\chi 2)$ test (significant if $\mathrm{p}<0.05$ ). Correlation between variables was done using sperman correlation.

\section{Results:}

Table(1): Demographic data of subjects included in this study:

\begin{tabular}{|c|c|c|}
\hline Parameter & $\begin{array}{c}\text { High risk cases }(\mathrm{n}=75) \\
\mathrm{n}(\%)\end{array}$ & $\begin{array}{c}\text { Controls } \\
(\mathbf{n}=40) \\
\mathbf{n}(\%)\end{array}$ \\
\hline $\begin{array}{l}\text { Age(years) } \\
20-25(71) \\
26-30(44) \\
\text { Mean age } \\
\end{array}$ & $\begin{array}{c}39(52.0 \%) \\
36(48.0 \%) \\
25.45\end{array}$ & $\begin{array}{c}32(80.0 \%) \\
8(20.0 \%) \\
24.15\end{array}$ \\
\hline $\begin{array}{l}\text { Time of samples } \\
\text { First trimester(27) } \\
\text { Second trimester(45) } \\
\text { Third trimester(43) }\end{array}$ & $\begin{array}{l}16(21.3 \%) \\
30(40.0 \%) \\
29(38.7 \%)\end{array}$ & $\begin{array}{l}11(27.5 \%) \\
15(37.5 \%) \\
14(35.0 \%)\end{array}$ \\
\hline $\begin{array}{l}\text { No. of abortion } \\
0(40) \\
2(69) \\
\geq 3(6)\end{array}$ & $\begin{array}{c}0(0.0 \%) \\
69(92.0 \%) \\
6(8.0 \%)\end{array}$ & $\begin{array}{c}40(100.0 \%) \\
\text { None } \\
\text { None }\end{array}$ \\
\hline $\begin{array}{l}\text { Residency } \\
\text { Urban }(87) \\
\text { Rural(28) } \\
\end{array}$ & $\begin{array}{l}57(76.0 \%) \\
18(24.0 \%) \\
\end{array}$ & $\begin{array}{l}30(75.0 \%) \\
10(25.0 \%)\end{array}$ \\
\hline $\begin{array}{l}\text { Eating raw meat } \\
\text { Yes }(32) \\
\mathrm{No}(83)\end{array}$ & $\begin{array}{l}23(30.7 \%) \\
52(69.3 \%)\end{array}$ & $\begin{array}{c}9(22.5 \%) \\
31(77.5 \%)\end{array}$ \\
\hline $\begin{array}{l}\text { Contact with cats } \\
\text { Yes }(29) \\
\text { No(86) }\end{array}$ & $\begin{array}{l}20(26.7 \%) \\
55(73.3 \%)\end{array}$ & $\begin{array}{c}9(22.5 \%) \\
31(77.5 \%) \\
\end{array}$ \\
\hline $\begin{array}{l}\text { Contact with soil } \\
\text { Yes }(73) \\
\operatorname{No}(42)\end{array}$ & $\begin{array}{l}62(82.7 \%) \\
13(17.3 \%)\end{array}$ & $\begin{array}{l}11(27.5 \%) \\
29(72.5 \%)\end{array}$ \\
\hline
\end{tabular}




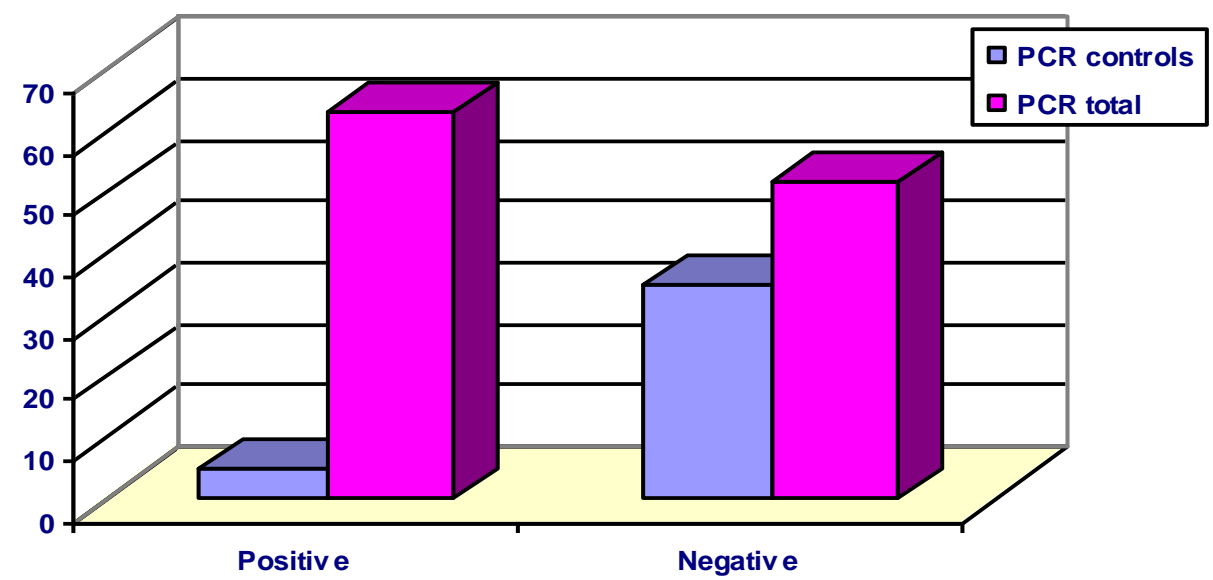

Fig.(1) PCR results in high risk cases and control group PCR was positive in 58(77.3\%) of cases and 5(12.5\%) of controls with highly significant increase PCR positivity in patient compared with controls $(\mathbf{p}<0.001)$

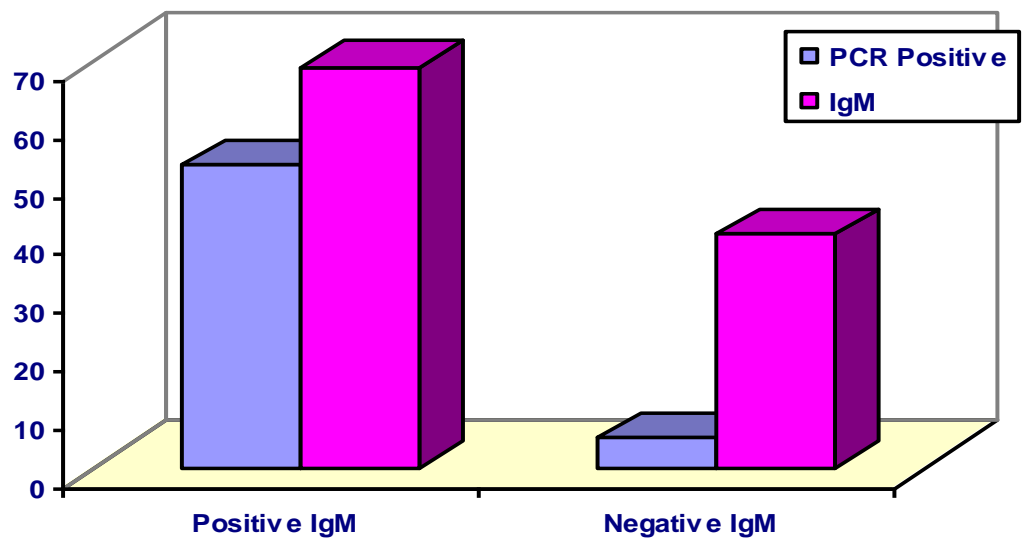

fig (2) PCR positivity in relation to IgM results 17 cases $(24.6 \%)$ had negative PCR result i.e. false positive and among 40 control with negative IgM, 5(12.5\%) had positive PCR i.e. false negative result with a highly significant association between positive PCR and positive IgM ( $\mathrm{p}=\mathbf{0 . 0 0 1})$.

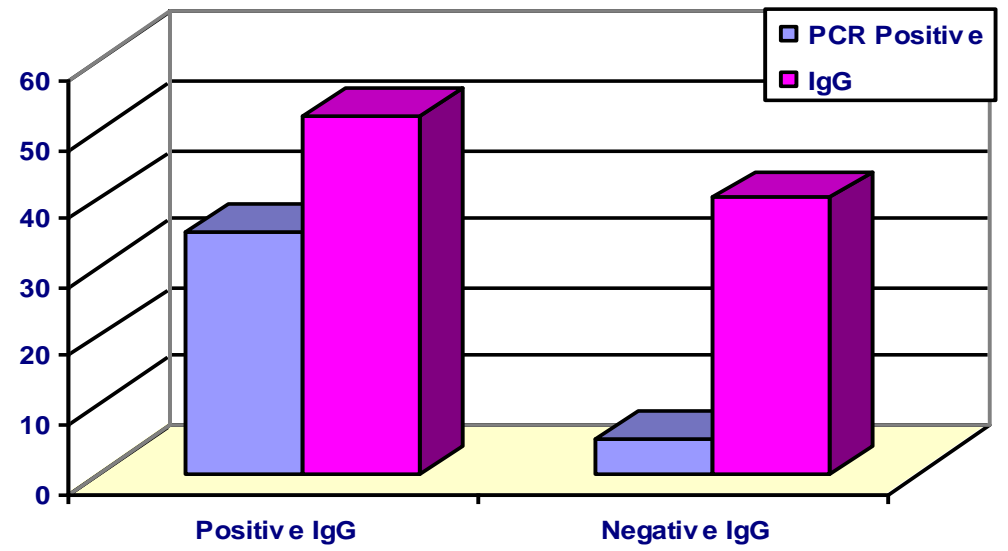

Fig (3) PCR positive in relation to IgG results Among 52 high risk cases positive IgG, 17(32.7\%) had negative PCR result i.e. false positive and among 40 control IgG, 5(12.5\%) had positive PCR result i.e. false negative with highly significant association between positive $P C R$ and positive IgG ( $p=0.0001)$. 
PCR detection of Toxoplasma gondii DNA versus serological.......

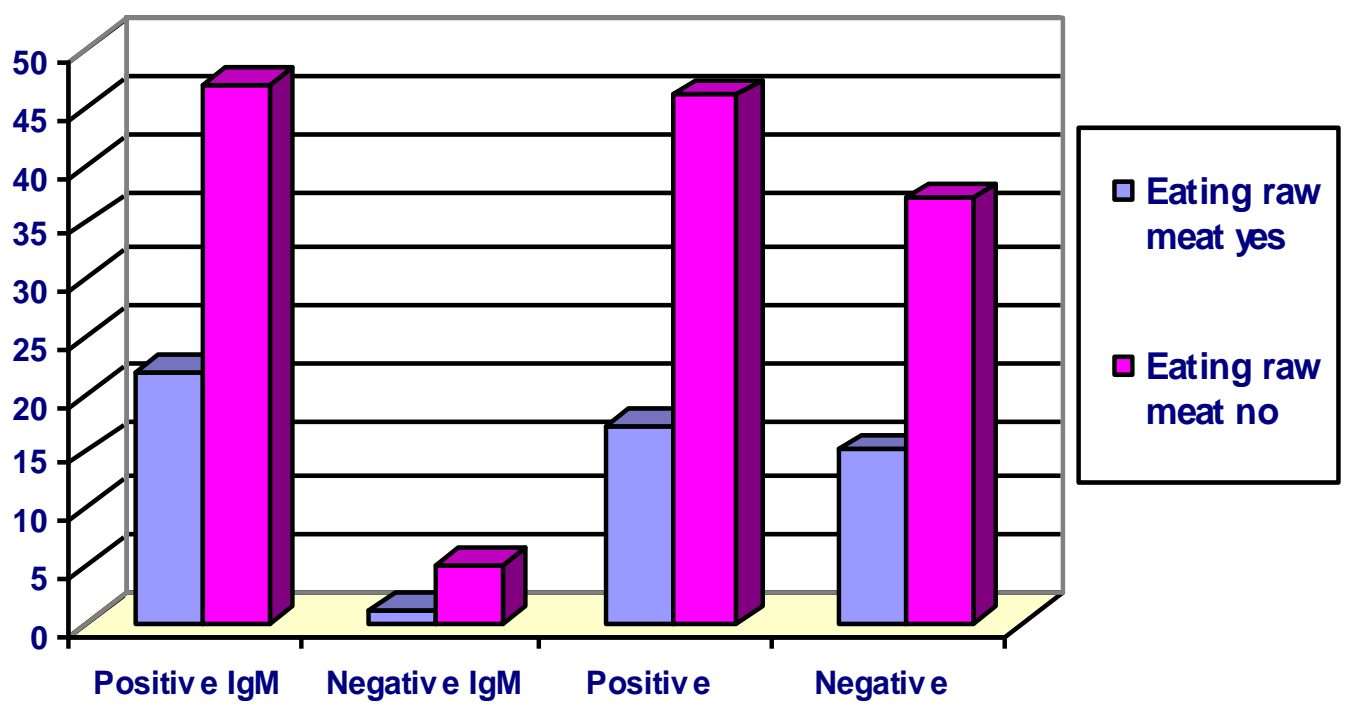

Fig (4) IgM and PCR result among high risk cases in relation to eating raw meat

This fig. showed no significant association between eating raw meat and positive IgM $(p>0.05)$ and also showed no significant association between eating raw meat and PCR (p>0.05) .

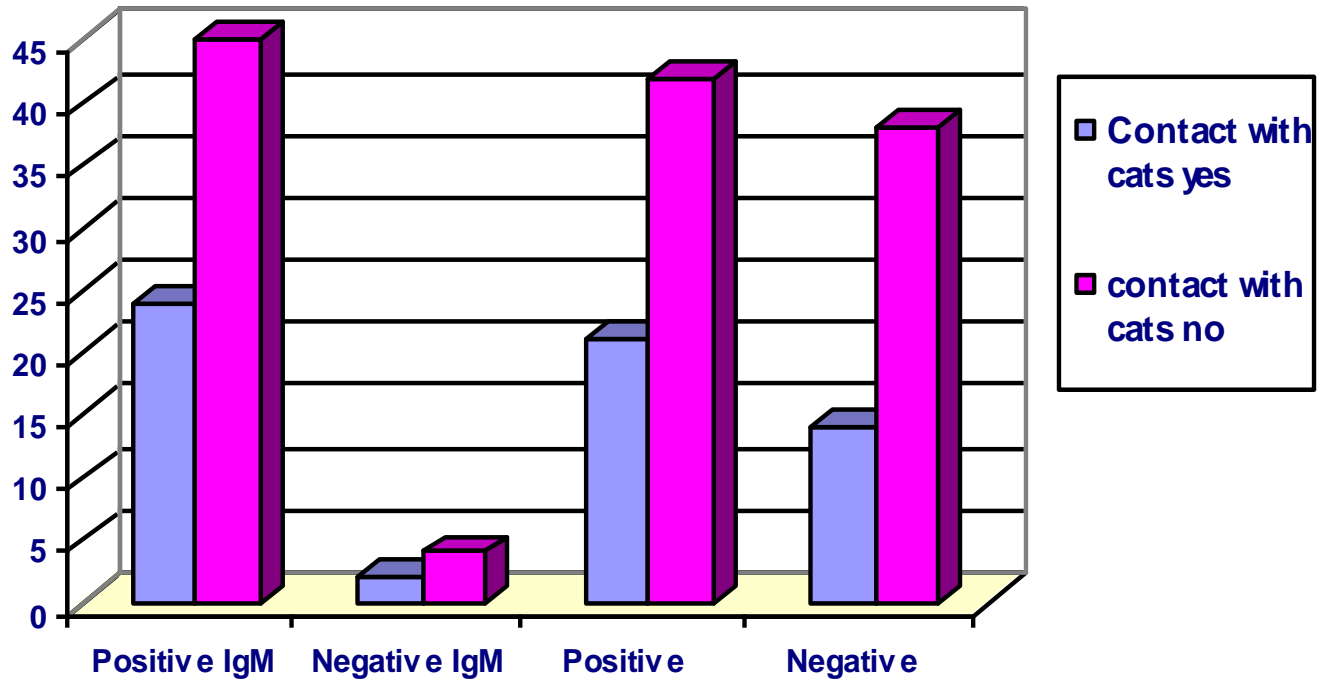

Fig (5) IgM and PCR result among high risk cases in relation to contact with cats.This Fig. showed no significant association between contact with cats and positive IgM $(p>0.05)$ and also showed no significant association between contact with cats cases and positivity of PCR $(p>0.05)$ 


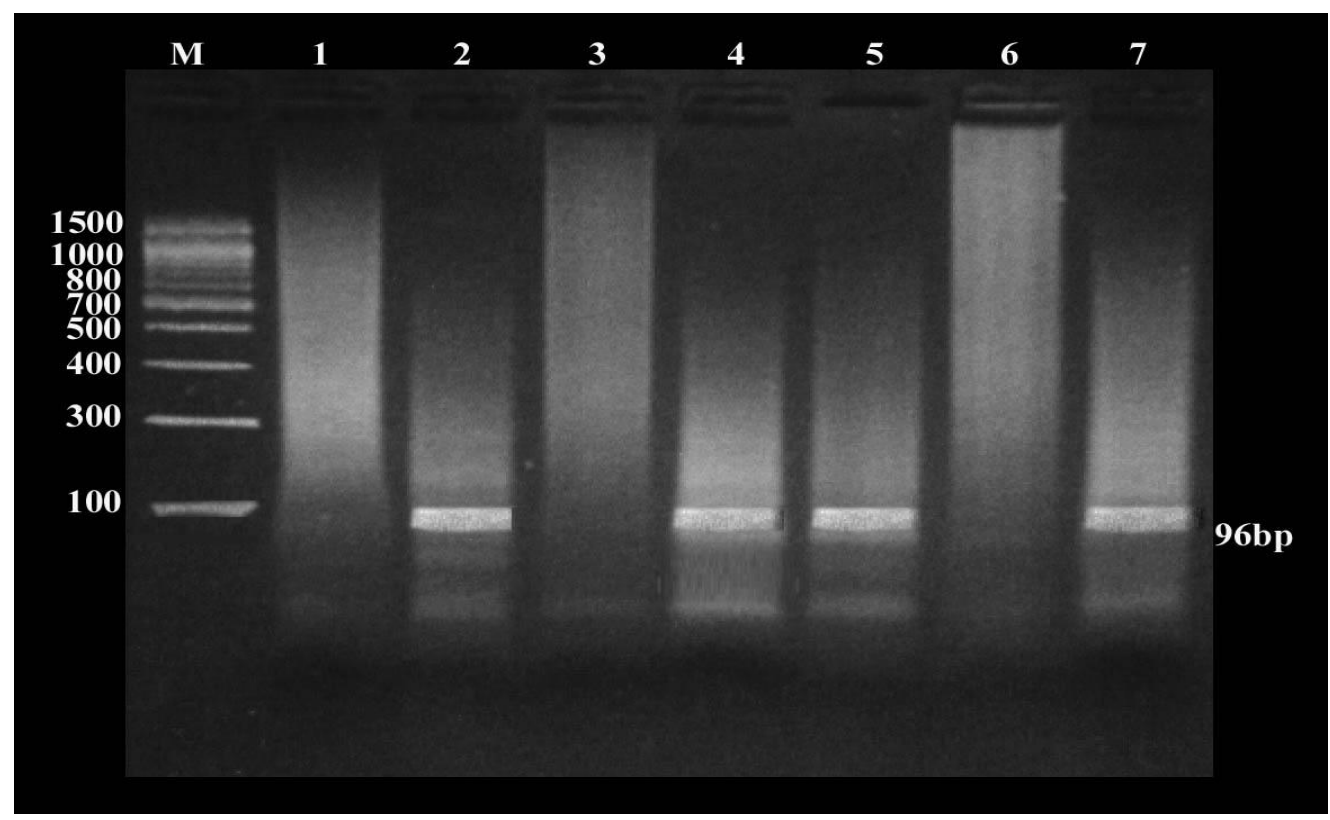

Fig (6) Toxoplasma gondii amplification DNA pattern Lane M is DNA marker, Lane 1 is Negative control without DNA, Lane 2 is positive control for PCR, Lane 3 and 6 are negative for PCR and Lane 4,5 and 7 are positive at $96 \mathrm{bp}$.

\section{Discussion}

Precise knowledge of acute T.gondii infections during pregnancy is needed for risk assessment of vertical transmission of infections as basis for counselings, prevention, and treatment (Vimercati et al., 2000). Fetal toxoplasmosis remains a significant disease as a result of acute parasitic infection in mothers not previously infected, consequences of infection are most severe if it occurs during the first trimester (Desmonts et al., 1985 and Daffos et al., 1998).

Toxoplasmosis can lead to a single pregnancy loss, and there are no confirmed studies to suggest that specific infections will lead to recurrent pregnancy loss in humans (Summers, 1994 and Regan et al., 2001). However, our cases were characterized by repeated abortion( $\geq 2$ pregnancy loss), this bad outcome is considered to be a risk factor for toxoplasmosis and repeated infection with T.gondii during pregnancy may explain this bad outcome, Table (1).

In the current study primary diagnosis of $T$.gondii infection in pregnant women at high risk (bad outcome, history of eating raw meat, contact with cats and contact with soil), depended on serological diagnosis with either positive antitoxoplasma IgG or IgM. Although serological testing has been the major diagnostic technique of toxoplasmosis it has many limitations because false positive results have been reported by other investigators (Hofgartner et al., 1997 and Wilson et al., 1997), in addition to the false negativity that may occur during the active phase of T.gondii infections (Lee et al., 1999 ), Table (1).

This study was conducted to test the utility of polymerase chain reaction (PCR) assay to detect recent infections with $T$.gondii in pregnant women. T.gondii DNA was detected by using B1 gene as a target for amplification which is highly specific for T.gondii and is well conserved among all of the tested strains (Burg et al., 1989).

Seventy five women with high-risk pregnancies who had abnormal pregnancy outcome and positive specific antibodies for Toxoplasma (cases) and forty women with normal pregnancy (controls) were tested for the presence of Toxoplasma DNA in their blood by a nested PCR.

The present study revealed the following findings:(1) PCR was positive in 
63 subjects, including 58 high risk cases $(77.3 \%)$ and 5 of controls (12.5\%), Figs (1), (2) showed that 17 high risk cases $(24.6 \%)$ had false positive IgM and 5 of controls $(12.5 \%)$ had false negative result for IgM, Figs (2), (3) showed that 17 high risk cases $(32.7 \%)$ had false positive IgG and 5 of controls (12.5\%) had false negative IgG, Figs (3), (4) showed no significant association between eating raw meat or contact with cats and positive ELISA or PCR, Fig.(4) detected highly significant association between women with contact with soil and positive PCR, Fig.(5). recoreded no significant relation between residency and either ELISA or PCR.

In Jordan, twenty $(13.5 \%)$ women with abnormal pregnancy outcomes compared with none in the control group were identified to be possibly infected during the current pregnancy (e.g., recent infection) based on the combined results of a positive IgG ELISA result (four were also positive for $\operatorname{IgM}$ ), and the detection of Toxoplasma DNA by a PCR assay. They were seronegative in the previous pregnancy. The negative results obtained by both the PCR and serology rule out an infection in the rest of women in both groups. Previous studies confirmed that the PCR could actually detect $T$. gondii in blood specimens of women before or during pregnancy (Hussein et al., 2002 and EL-Awady et al., 2000).

A previous study of serial blood samples from acutely infected pregnant women indicated that in the presence of toxoplasma-specific IgG and $\operatorname{IgM}$ antibodies, and the additional presence of a high dye test titer were insufficient criteria for identifying toxoplasma infection in early pregnancy because some acute infections will not be detected (Jenum et al., 1997). Conversely, some women will be falsely identified as being infected, (Liesenfeld et al., 2001) and undergo unnecessary diagnostic amniocentesis and antiparasitic treatment (Jenum et al., 1997). In a study of uterine Toxoplasma infections in women with repeated abortions, five $(71.4 \%)$ of seven toxoplasma-positive endometrium patients were serologically negative. These reports emphasize the importance of confirmatory testing (Stray-Pedersen and Lorentzen, 1977).
In the current study, the risk factor strongly associated with acute infection in PCR-positive women is contact with soil, although eating raw meats and contact with cats are also associated risk factors. Nimri et al. (2004) found that the risk factors strongly associated with acute infection in the IgG-positive and PCR-positive women were eating raw meat and contact with soil.

Moreover, Cook et al. (2000) reported that risk factors most strongly predictive of acute infection in pregnant women were eating undercooked lamb, beef or game and contact with soil, and that contact with cats was not a risk factor. They also concluded that preventive strategy should aim to reduce prevalence of infection in meat, improve labelling of meat according to farming and processing methods and improve quality and consistency of health information given to pregnant women.

Similar to The present study, Jenum et al. (1998) reported that the incidence of T. gondii for women living in urban areas was not significantly different from that living in rural areas.

In the present study, among 63 PCR positive pregnancy women, 48 of them were living in urban area with no significant association between residence of the studied groups and positivity of PCR. However, the high frequency of cases living in urban area may be related to exposure to risk factors in urban area as eating raw meats as well as contact with cats.

As regards the age of pregnant women with T.gondii; our study showed a significant negative correlation between the age and the positivity of PCR. This means that infection with T.gondii is more frequent in young pregnant women (mean age $25.45 \pm 2.03$ years). This can be explained by the fact that the child-bearing period starts after marriage with desire of having offspring early, in addition to exposure to risk factors is more common among young women.

As soon as the primary maternal T.gondii infection was confirmed, the women was counseled by one of the investigators. An ultrasound examination of the fetus was performed, and the women was offered amniocentesis, performed as soon as possible but no earlier than the $12^{\text {th }}$ week of gestation (Desmonts et al., 1985 
and Jenum et al., 1998). Antiparasitic treatment including spiramycin (before the $18^{\text {th }}$ week of gestation) and/or pyrimethamine, sulfonamide, and folinic acid (after the $18^{\text {th }}$ week of gestation) according to published guidelines was recommended for all women (StrayPedersen, 1993).

In conclusion: this study highlights the need for a confirmatory test to detect primary acute toxoplasmosis in pregnant women. It demonstrates the possibility of defining and selecting the high-risk cases for mother-to-child transmission of infection by combining specific serology and PCR tests to formulate a specific approach.

\section{References}

1. Bergstrom $\mathbf{T}$, Ricksten $\mathbf{A}$, Nenonen $\mathbf{N}$, Lichtenstein M, Olofsson S (1998): congenital Toxoplasma gondii infection diagnosed by PCR amplification of peripheral mononuclear blood cells from a child and mother. Scand J. Infect. Dis., 30: 202-204.

2. Burg JL, Grover CM, Poulety P, Boothroyd JC (1989): Direct and sensitive detection of a pathogenic protozoan, Toxoplasma gondii by polymerase chain reaction. J. Clin. Microbiol, 27: 1787-1792.

3. Cook DC, Gilbert RE, Buffolano W, Zufferey J, Petersen E, Jenum PA, Foulon W, Semprini AE, Dunn DT (2000): Sources of Toxoplasma infection in pregnant women: European multicentre case-control study. BMJ., 21: 142-147.

4. Costa JM, Darde M-L, Assouline B, vidaud M, Bretagne S (1997): Microsatellite in the beta- tubline gene of Toxoplasma gondii as a new genetic marker for use in direct screening of amniotic fluids. J. Clin. Microbiol., 35:2542-2545.

5. Daffos F, Forestier F, Capella Pavlovsky M (1998): Prenatal management of 746 pregnancies at risk for congenital toxoplasmosis. N. Eng. J. Med., 318 : $271-275$.

6. Desmonts G F, Daffos F, Forestier M, Capella-Pavlvsky P, Thulliez and Chartier M (1985): Prenatal diagnosis of congenital toxoplasmosis.Lancet, i: 500-504.

7. Dubey JP and Beattie CP (1988) Toxoplasmosis of animals and Man. Baca Raton, Florida, 52.

8. El-Awady MK, el-Hosseiny LA, Ismail SM, Abdel-Aziz MT, el-Demellawy MA (2000): Comparison between Toxoplasma gondii DNA and specific immunoglobulins during pregnancy. East Mediterr Health J., 6: 888-897

9. Gange SS (2001): Toxoplasmosis, prim care update obstet Gynecol., 8 : 122 - 126.

10. Ho - Yen Do, Joss Awl, Balfour AH, Smyth ETM, Baird D, Chatterton JMW (1992): Use of the Polymerase chain reaction to detect $\mathbf{T}$.gondii in human blood samples. J. Clin. Pathol., 45 : 910 - 913.

11. Hofgärtner WT, Swanzy SR, Bacina RM, Condon J, Gupta M, Matlock PE, Bergeron DL, Plorde JJ, Fritsche TR (1997): Detection of immunoglobulin G (IgG) and $\operatorname{IgM}$ antibodies to T.gondii: evaluation of four commercial immunoassay systems. J. Clin. Microbiol., 35: 3313-3315.

12. Hohlfeld P, Daffosf Costa J-M, Thulliez P, Forestier F, Vidaud M (1994): Prenatal diagnosis of congenital toxoplasmosis with a polymerase chain reaction test on amniotic fluid. N. Eng.I.Med.,331: 695-699.

13. Hussein AH, Nagaty IM, Fouad MA (2002): Evaluation of IgM ELISA versus PCR in diagnosis of recent T.gondii infection. J. Egypt Soc. Parasitol., 32: 639646.

14. Jenum $\mathbf{P}$ A M, Holberg-Petersen $\mathbf{K} \mathbf{K}$, Melby and Stray-Pedersen B (1998): Diagnosis of congenital T.gondii infection by polymerase chain reaction (PCR) on amniotic fluid samples. The Norwegian experience. Acta Pathol. Microbiol. Immunol. Scand., 106:680-686.

15. Jenum P, Stray-Pedersen B, Gundersen AG (1997): Improved diagnosis of primary T.gondii infection in early pregnancy by determination of antitoxoplasma immunoglobulin G Avidity. J. Clin. Microbiol., 35: 1972-1977.

16. Johnson JD, Butcher PD, Savva D, Holliman RE (1993): Application of the Poly merase chain reaction to the diagnosis of human toxoplasmosis. J. Infect., 26:147158.

17. Joss Awl, chatterton JMW, Evans R, Hoyen Do (1999): Toxoplasma polymerase chain reaction on experimental blood samples. J. Med. Microbiol., 38:38 - 43.

18. Kopecky D, Hayed M, Prusa AR, Adlassnig KP (2001): Knowledge based interpretation of toxoplasmosis serology test results including fuzzy temporal concepts the Toxo. Net System. Med. Info., $10: 484$ 488.

19. Lee PYC, Mangan J, Holliman RE, Butcher PD (1999): Quantitation of Toxoplasma gondii DNA in a competitive nested polymerase chain reaction. J. Clin. Pathol., 52:61-64. 
20. Liesenfeld O, Montoya JG, Tathinen NJ, Davis M, Brown BW, Cobb KL, Parsonet J, Remington JS (2001): Confirmatory serologic testing for acute toxoplasmsis and rate of induced abortions among women reported to have positive Toxoplasma immunoglobulin $\mathrm{M}$ antibody titers. Am. J. Obstet. Gynecol., 184: 140-145.

21. Nimri L, Pelloux H, El-Khatib L (2004): Detection of T.gondii DNA and specific antibodies in high-risk pregnant women, Am. J. Trop. Med. Hyg., 71(6); 831-835.

22. Pujol-Rique M, Derouin F, GarciaQuintanilla A, Valls ME, Miro JM, Jimenez de Anta MT (1999): Design of aone. tube hemi - nested PCR for detection of T.gondii and comparsion of three DNA purification methods. J. Med. Microbiol., 48: 857-862.

23. Regan L, Rai R, Backos M, El Gaddal S (2001): Recurrent miscarriage and parental karyotype abnormalities: prevalence and future pregnancy outcome. Hum. Reprod., 16:177-178.

24. Remington JS, Mcleod R, Desmonts G, Remington, JS, Klein JO (1995): Toxoplasmosis eds. Infectious Diseases of the Fetus and Newborn Infant., 140-267.

25. Roberts CW, Walker W, Alexander J (2001): Sex- associated hormones and immunity to protozoan parasites. Clin. Microbiol. Rev., 14 : 476 - 488.

26. Sahwi SY, Zaki MS, Haiba NY, El Said OK, Anwar MY (1995): Toxoplasmosis as acause of repeated abortion. J. Obstet. Gynaecol., 21: 145-148.

27. Stray-Pedersen B (1993): Toxoplasmosis in pregnancy. Clin. Obstet. Gynaecol., 7:107-137.

28. Stray-Pedersen B, Lorentzen-Styr AM (1977): Uterine Toxoplasma infections and repeated abortions. Am. J. Obstet. Gynecol., 128: 716-721.

29. Summers PR (1994): Microbiology relevant to recurrent miscarriage. Clin. Obstet. Gynecol., 37: 722-729.

30. Vimercati A, Greco P, D'apolito A, Angelici MC, Possenti A, Carbonara S, Selvaggil L (2000): Risk assessment of vertical transmission of Toxoplasma infections. 71: 537-540.

31. Wilson M, Remington JS, Clavet C, Varney G, Press C, Ware D (1997): Evaluation of six commercial kits for the detection of immunoglobulin $\mathrm{M}$ antibodies to T.gondii, [The FDA Toxoplasmosis Ad Hoc Working Group.] J. Clin. Microbiol., 35: 3112-3115.

32. Wong SY, Remington JS (1994): Toxoplasmosis in pregnancy. Clin. Infect. Dis., 18 : 853 - 861 .

33. Zargar AH, Wani AI, Masood SR, Laway BA, Kakro DK, Thokar MA, Sofi BA, Bashir MI (1999): Seroprevalence of Toxoplasmosis in women with recurrent abortions / neonatal deaths and its treatment outcome. Indian J. Pathol. Microbiol., 42 : $384-486$. 


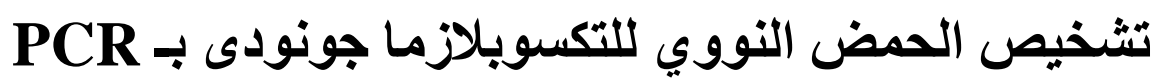

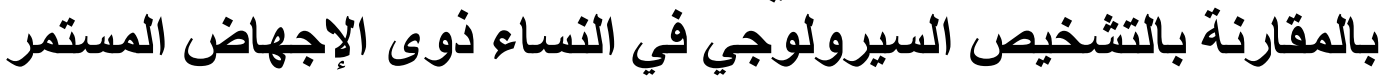

\section{أمورة محمد أبو النجا، على على شلتوت، رزق أحمد الباز، إيمان محمد فياض فئن قسم علم الحيوان - كلية العلوم -جامعة المنصورة ـ مصر}

لقد أجريت هذه الدراسة في كلية العلوم جامعه المنصورة وتم أخذ موافقة من

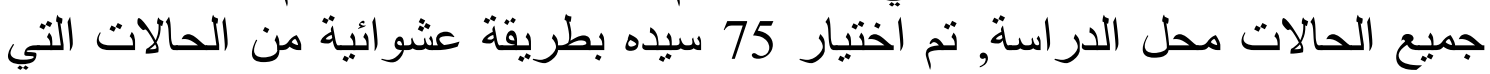

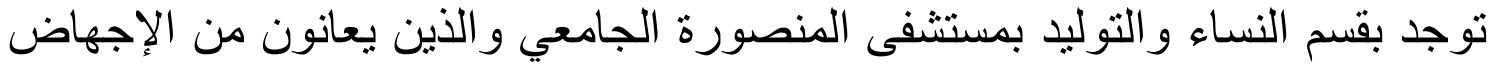

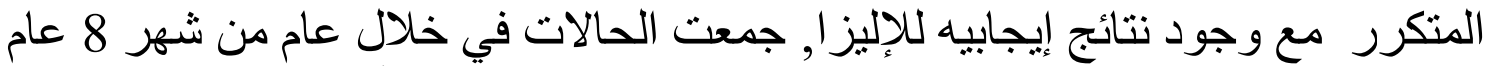

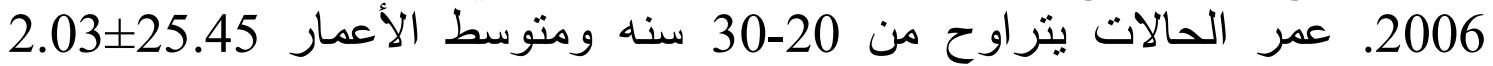

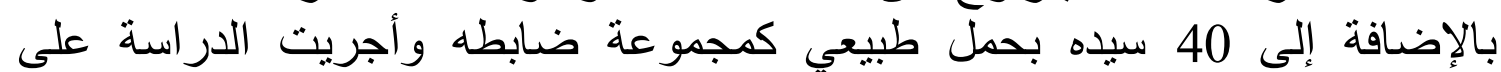

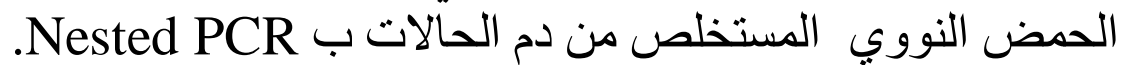

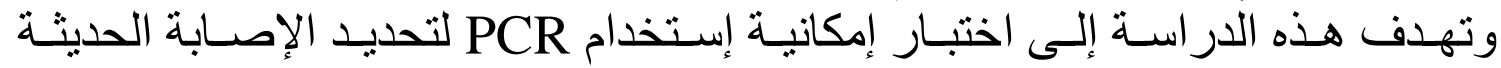

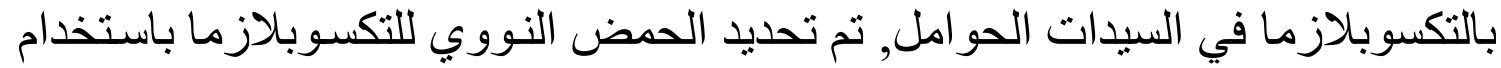

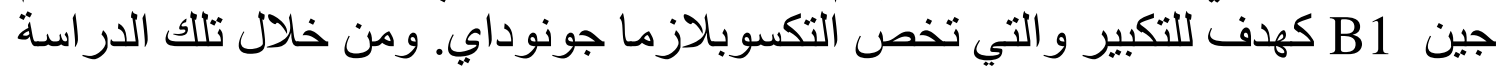
توصلنا إلى النتائج التالية:

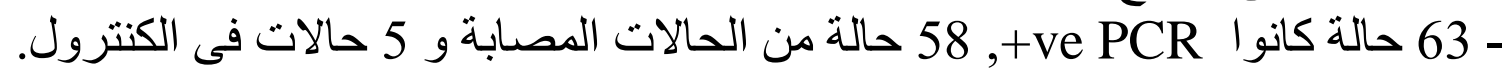

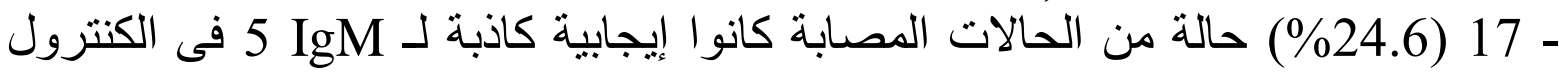
كانو ا سلبية كاذبة لـ الـ من الحالات ـ 17(32.7\%) حالة من الحالات المصابة كانوا إيجابية كاذبة لـ 5 الـ كلى الكنترول

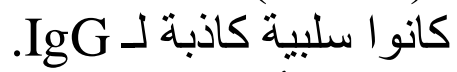

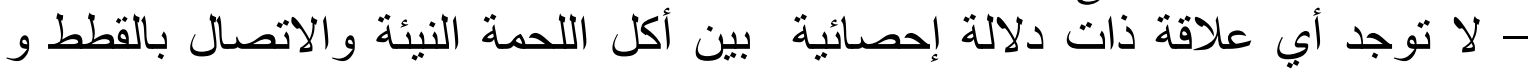

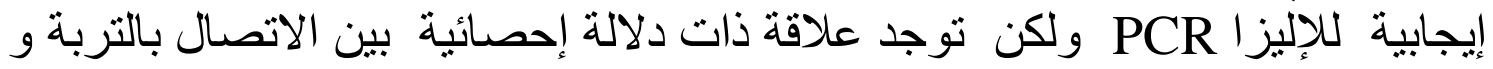

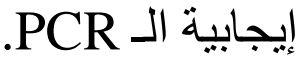

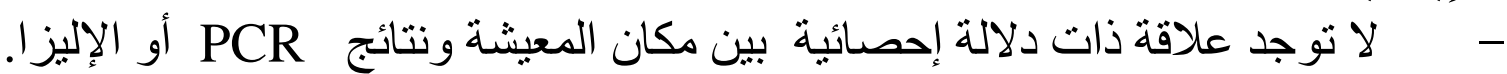
- مايوجد ارتباط سلبي ذو دلالة إحصائية بين عمر السيدات الحوامل محل الدراسة

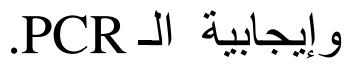

